\title{
SUCCESSFUL MEDICAL THERAPY OF ACANTHAMOEBA KERATITIS WITH TOPICAL CHLORHEXIDINE AND PROPAMIDINE
}

\author{
DAVID SEAL ${ }^{1}$, JOHN HAY ${ }^{1}$, COLIN KIRKNESS ${ }^{1}$, ANDREW MORRELL ${ }^{2}$, ADAM BOOTH ${ }^{2}$, \\ ANDREW TULLO ${ }^{3}$, ALAN RIDGWAY ${ }^{3}$ and MALCOLM ARMSTRONG ${ }^{3}$ \\ Glasgow, Leeds and Manchester
}

\begin{abstract}
SUMMARY
Introduction. Following laboratory studies on new potential chemotherapy for Acanthamoeba keratitis, when chlorhexidine and propamidine provided an additive in vitro effect, a series of 12 patients with culture-proven Acanthamoeba keratitis from three UK centres was monitored during and after therapy.

Methods. In all cases the clinical diagnosis was confirmed by amoebal culture. In some instances identification of the protozoa by direct microscopy of corneal tissue was possible. The medication was provided topically in drop form until the keratitis had resolved. In vitro sensitivity to chlorhexidine and propamidine was performed on all isolates and compared with sensitivity to a range of other drugs used for treatment of the infection.

Results. In vitro drug testing confirmed that trophozoites and cysts of all 12 Acanthamoeba isolates were fully sensitive to chlorhexidine and propamidine. Therapy was satisfactory for controlling and eradicating the acanthamoebal infection in all patients. Three patients developed discrete stromal infiltration at the site of infection that resolved 1 week after commencing therapy, with or without use of steroids. Two patients developed a late inflammatory effect in the stromal scar at 6 months, which resolved with steroids. No clinical evidence of chlorhexidine toxicity was found in any patient.
\end{abstract}

Conclusions. The combination of topical chlorhexidine and propamidine was very effective for treating Acanthamoeba keratitis provided the drugs were continued for a sufficient period. No drug toxicity or

From: ${ }^{1}$ Tennent Institute of Ophthalmology, Western Infirmary, Glasgow; ${ }^{2}$ Department of Ophthalmology, St James's University Hospital, Leeds; ${ }^{3}$ Departments of Ophthalmology and Microbiology, Royal Eye Hospital and Infirmary, Manchester, UK:

Correspondence to: Dr D. V. Seal, MD, FRCOphth, FRCPath, Tennent Institute of Ophthalmology, Western Infirmary, Glasgow G11 6NT, UK. Fax: +44 (141)-552-3037. resistance of Acanthamoeba isolates was observed in the 12 treated patients.

Acanthamoeba keratitis is a sight-threatening infection. Until recently, there has been a limited medical, therapeutic armamentarium. Although a diverse range of drugs has been suggested for treatment of this disease, medical cure was first reported in 1985 with a combination of propamidine and neomycin. ${ }^{1}$ The limited overall success of this combination has necessitated a continued quest for alternative, improved therapy. ${ }^{2-4}$

In one study of in vitro sensitivity of corneal isolates of Acanthamoeba to a range of candidate drugs, chlorhexidine was found to be the most active single acanthamoebicidal compound; it was also shown to be effective in a pilot study involving two patients with culture-proven infection. ${ }^{4}$ Others have subsequently shown chlorhexidine to be acanthamoebicidal in vitro. ${ }^{5,6}$ The related compound polyhexamethylene biguanide (PHMB) is also acanthamoebicidal and its use can result in early and effective medical treatment. ${ }^{2,3}$ PHMB is not licensed, however, for medical use, ${ }^{7}$ although it has gained approval for inclusion as a disinfectant in certain cold-chemical soft contact lens solutions.

Chlorhexidine is a bis-biguanide while PHMB is a polymeric biguanide. Both these compounds are effective acanthamoebicides. They are thought to act via interaction between the electropositive biguanide groups and the plasma membrane; the drugs may compromise the integrity of the mucopolysaccharide plug that seals the ostiole of the cyst, although other factors are likely to be involved. The lethal action of these compounds is due primarily to the irreversible loss of essential cellular components through the damaged plasmalemma of the amoeba. Cytoplasmic precipitation is a secondary event. Mole for mole, the

Eye (1996) 10, 413-421 (C) 1996 Royal College of Ophthalmologists 
Table I. Demographic and optometric details of patients with Acanthamoeba keratitis and their contact lenses

\begin{tabular}{|c|c|c|c|c|c|c|c|c|}
\hline Patient & $\begin{array}{c}\text { Age } \\
\text { (years) }\end{array}$ & Sex & Occupation & Location & $\begin{array}{l}\text { Contact lens } \\
\text { trade name }\end{array}$ & $\begin{array}{l}\text { FDA lens } \\
\text { group }\end{array}$ & $\begin{array}{l}\text { Replacement } \\
\text { schedule (weekly) }\end{array}$ & $\begin{array}{l}\text { Contact lens } \\
\text { disinfectant }\end{array}$ \\
\hline 1 & 50 & $\mathrm{M}$ & Teacher & Glasgow & $\mathrm{Hema}^{\mathrm{a}}$ & 1 & None & None \\
\hline 2 & 25 & $\mathrm{~F}$ & Administrator & Glasgow & Acuvue $^{\mathrm{d}}$ & 4 & Four & Chlorine $^{\mathrm{b}}$ \\
\hline 3 & 50 & $\mathrm{~F}$ & Social worker & Glasgow & Surevue ${ }^{\mathrm{d}}$ & 4 & Four & Chlorine $^{b}$ \\
\hline 4 & 27 & $M$ & Surveyor & Glasgow & Acuvue $^{\mathrm{d}}$ & 4 & Four & Chlorine $^{\mathrm{b}}$ \\
\hline 5 & 32 & M & Chiropodist & Glasgow & Acuvue $^{\mathrm{d}}$ & 4 & Four & Chlorine $^{\mathrm{b}}$ \\
\hline 6 & 31 & $\mathrm{~F}$ & Housewife & Leeds & Igel $38^{\mathrm{e}}$ & 1 & Intermittent & Chlorine $^{b}$ \\
\hline 7 & 27 & $\mathrm{~F}$ & Housewife & Edinburgh & Acuvue $^{\mathrm{d}}$ & 4 & Intermittent & Hydrogen peroxide \\
\hline 8 & 24 & $\mathrm{M}$ & Legal exec. & Manchester & Acuvue $^{\mathrm{d}}$ & 4 & Two & Chlorine ${ }^{\mathrm{b}}$ \\
\hline 9 & 14 & $\mathrm{~F}$ & Schoolgirl & Manchester & Acuvue $^{\mathrm{d}}$ & 4 & Four & Chlorine $^{\mathrm{b}}$ \\
\hline 10 & 32 & $\mathrm{~F}$ & Clerk & Manchester & Hydrogel $^{\mathrm{a}}$ & 1 or 2 & $\begin{array}{l}\text { None (lens } 2 \\
\text { months old) }\end{array}$ & Hydrogen peroxide \\
\hline 11 & 21 & M & Student & Manchester & Aspect $55^{\mathrm{f}}$ & 4 & Four & Chlorine $^{\mathrm{b}}$ \\
\hline 12 & 38 & $\mathrm{~F}$ & Housewife & Ayr & Acuvue $^{\mathrm{d}}$ & 4 & Four & Chlorine $^{\mathrm{b}}$ \\
\hline
\end{tabular}

${ }^{\mathrm{a}}$ Type of contact lens not known. ${ }^{\mathrm{b}}$ Softab (Alcon). ${ }^{\mathrm{c}}$ Replaced with tap water. ${ }^{\mathrm{d}}$ Etafilcon A. ${ }^{\mathrm{e}}$ Filcon la. ${ }^{\mathrm{f}}$ Most probable type, hema copolymer.

polymeric biguanide should be more effective than the bis-biguanide, but non-specific binding due to residual positive charges on the polymer may reduce the activity of the PHMB, relative to chlorhexidine, in the presence of anionic charges. This phenomenon, however, has yet to be proven in vivo within the cornea.

The findings are presented of a multi-centre study evaluating the effect of continuous topical treatment with chlorhexidine, in combination with propamidine (as Brolene), of 12 cases of culture-proven Acanthamoeba keratitis as first-line therapy.

\section{Patients}

\section{METHODS}

All 12 contact-lens-wearing patients (Table I) had the clinical diagnosis of Acanthamoeba keratitis confirmed by isolation of the protozoan from corneal scrape or biopsy. None of the 12 was treated with any other known acanthamoebicidal drug either prior to presentation or during the course of the disease. All 12 patients were treated with topical chlorhexidine (di)gluconate $(0.02 \%)$ and propamidine (as Brolene, $0.1 \%$ ), and were followed up for at least 6 months following cessation of treatment. No patient who commenced the therapy described was withdrawn from the study. Brief histories of two patients (nos. 1 and 6) reported here have been recorded elsewhere. $^{4,8}$

\section{Isolation of Acanthamoeba}

All 12 patients had corneal scrapes cultured for Acanthamoeba. These were initially inoculated onto non-nutrient agar plates, seeded with Gram-negative coliform bacteria. ${ }^{9}, 10$ The plates were incubated at $25^{\circ} \mathrm{C}$ or $32^{\circ} \mathrm{C}$ for at least 7 days. In Glasgow, a wet film preparation of the corneal scrape was also examined using bright field and/or phase-contrast microscopy. ${ }^{10}$

Isolates from Leeds and Manchester were forwarded to the Tennent Institute, Glasgow, for drug sensitivity testing. This ensured adequate quality control since the same method with identical assay conditions was used for all isolates.

\section{Drug Sensitivity Testing}

All 12 Acanthamoeba isolates from the cornea of each patient were tested as previously described. ${ }^{4}$ Briefly, $100 \mu \mathrm{l}$ containing approximately $2 \times 10^{4}$ trophozoites or cysts was instilled into each well of microtitre plates; $100 \mu \mathrm{l}$ aliquots of doubling dilutions $(100-0.8 \mu \mathrm{g} / \mathrm{ml})$ of the following cationic surfactants or drugs were added: chlorhexidine (di)gluconate, alexidine (a related bis-biguanide), polyhexamethylene biguanide, propamidine isethionate, pentamidine isethionate, hexamidine isethionate and neomycin sulphate. Sealed plates were mixed gently for 10 minutes on a plate rotator and incubated for 48 hours in air at $32{ }^{\circ} \mathrm{C}$.

After removal of residual drug and instillation of a defined medium, plates were reincubated for a further 48 hours. During this time wells were inspected microscopically for the lowest concentration of drug that resulted in complete lysis or degeneration of trophozoites (minimum trophozoite amoebacidal concentration, MTAC) or, for cysts, the lowest concentration of test compound that resulted in no excystment (minimum cysticidal concentration, MCC).

\section{RESULTS}

Patients were started on intensive 3 day dosing regimens, with chlorhexidine (at $200 \mu \mathrm{g} / \mathrm{ml}, 0.02 \%$ ) and propamidine (as Brolene, at $1000 \mu \mathrm{g} / \mathrm{ml}, 0.1 \%$ ) drops being applied every other hour day and night for 3 days. On completion of this regimen, the dosage was reduced to 2 -hourly by day for 4 weeks, followed by 3 -hourly by day for 4 weeks and then 4-hourly by day, for a further period until all signs and symptoms of the infection had regressed. Therapy was withdrawn when the eyes appeared uninflamed and when no clinical signs suggestive of continuing infection 
Table II. Diagnosis, initial treatment, clinical response and complications

\begin{tabular}{|c|c|c|c|c|c|c|c|c|c|c|}
\hline Patient & Initial diagnosis & Initial treatment & $\begin{array}{l}\text { Delay to } \\
\text { diagnosis } \\
\text { (weeks) }\end{array}$ & $\begin{array}{l}\text { Clinical appearance } \\
\text { at diagnosis }\end{array}$ & Isolate and method & $\begin{array}{l}\text { Resolution } \\
\text { of symptoms } \\
\text { (weeks) }\end{array}$ & $\begin{array}{l}\text { Resolution } \\
\text { of signs } \\
\text { (weeks) }\end{array}$ & $\begin{array}{l}\text { VA pre- } \\
\text { therapy }\end{array}$ & $\begin{array}{c}\text { VA } \\
\text { post- } \\
\text { therapy }\end{array}$ & Complications \\
\hline$\overline{1}$ & HSK, disciform & $\mathrm{F}_{3} \mathrm{~T}$, dexamethasone & 14 & $\begin{array}{l}\text { Ring infiltrate, } \\
\text { oedema }\end{array}$ & Acanthamoeba biopsy & 7 & $>11$ & $3 / 60$ & $6 / 6$ & $\begin{array}{l}\text { Secondary streptococcal } \\
\text { infection; PK }\end{array}$ \\
\hline 2 & HSK, ulcer & Acyclovir & 6 & $\begin{array}{l}\text { Ulcer, ring infiltrate, } \\
\text { keratoneuritis }\end{array}$ & $\begin{array}{l}\text { Acanthamoeba } \\
\text { epithelial scrape }\end{array}$ & 2 & 28 & $\mathrm{CF}$ & $6 / 18$ & $\begin{array}{l}\text { Late immuno- } \\
\text { inflammatory reaction, } \\
\text { resolved with topical } \\
\text { steroids }\end{array}$ \\
\hline 3 & $\begin{array}{l}\text { Acanthamoeba } \\
\text { keratitis }\end{array}$ & $\begin{array}{l}\text { Brolene, } \\
\text { chlorhexidine }\end{array}$ & 3 & $\begin{array}{l}\text { Epithelial infiltrates, } \\
\text { limbitis }\end{array}$ & $\begin{array}{l}\text { Acanthamoeba } \\
\text { epithelial scrape }\end{array}$ & 4 & 12 & $6 / 60$ & $6 / 9$ & None \\
\hline 4 & Presumed bacterial & $\begin{array}{l}\text { Penicillin, } \\
\text { chloramphenicol }\end{array}$ & 1 & $\begin{array}{l}\text { Discrete epithelial } \\
\text { infiltrates, } \\
\text { keratoneuritis }\end{array}$ & $\begin{array}{l}\text { Acanthamoeba }+ \\
\text { Vahlkampfia } \\
\text { epithelial scrape }\end{array}$ & 1 & 4 & $6 / 24$ & $6 / 9$ & None \\
\hline 5 & Adenovirus keratitis & $\begin{array}{l}\text { Chloramphenicol, } \\
\text { gentamicin }\end{array}$ & 2 & $\begin{array}{l}\text { Epithelial micro- } \\
\text { abscesses, infiltrates }\end{array}$ & $\begin{array}{l}\text { A. griffini epithelial } \\
\text { scrape }\end{array}$ & 4 & 8 & $6 / 60$ & $6 / 5$ & None \\
\hline 6 & HSK & $\begin{array}{l}\text { Acyclovir, steroids, } \\
\text { chloramphenicol, } \\
\text { gentamicin }\end{array}$ & 9 & $\begin{array}{l}\text { Infiltrate, ulcer, } \\
\text { keratoneuritis, } \\
\text { limbitis }\end{array}$ & Acanthamoeba biopsy & 1 & 7 & $6 / 5$ & $6 / 4$ & $\begin{array}{l}\text { Early stromal oedema, } \\
\text { resolved without topical } \\
\text { steroids }\end{array}$ \\
\hline 7 & HSK & Acyclovir & 4 & $\begin{array}{l}\text { Epithelial oedema, } \\
\text { keratoneuritis }\end{array}$ & $\begin{array}{l}\text { Acanthamoeba } \\
\text { epithelial scrape }\end{array}$ & 1 & 5 & $6 / 36$ & $6 / 6$ & None \\
\hline 8 & HSK & $\begin{array}{l}\text { Acyclovir, } \\
\text { chloramphenicol }\end{array}$ & 2 & $\begin{array}{l}\text { Punctate } \\
\text { epitheliopathy, } \\
\text { limbitis }\end{array}$ & $\begin{array}{l}\text { Acanthamoeba } \\
\text { epithelial scrape }\end{array}$ & 4 & 8 & $6 / 60$ & $6 / 6$ & None \\
\hline 9 & HSK & $\begin{array}{l}\text { Acyclovir, } \\
\text { chloramphenicol }\end{array}$ & 1 & $\begin{array}{l}\text { Epithelial oedema, } \\
\text { dendriform ulcer }\end{array}$ & $\begin{array}{l}\text { Acanthamoeba } \\
\text { epithelial scrape }\end{array}$ & 1 & 12 & $1 / 60$ & $6 / 6$ & $\begin{array}{l}\text { Early stromal oedema, } \\
\text { resolved without steroids; } \\
\text { late immuno-inflammation } \\
\text { required topical steroids }\end{array}$ \\
\hline 10 & $\begin{array}{l}\text { Blepharokerato- } \\
\text { conjunctivitis }\end{array}$ & $\begin{array}{l}\text { Tetracycline, } \\
\text { prednisolone }\end{array}$ & 2 & $\begin{array}{l}\text { Epithelial infiltrates, } \\
\text { keratoneuritis }\end{array}$ & $\begin{array}{l}\text { Acanthamoeba } \\
\text { epithelial scrape }\end{array}$ & 2 & 17 & $3 / 36$ & $6 / 9$ & Toxicity to Brolene \\
\hline 11 & $\begin{array}{l}\text { Acanthamoeba } \\
\text { keratitis }\end{array}$ & $\begin{array}{l}\text { Propamidine, } \\
\text { gentamicin, } \\
\text { cefuroxime }\end{array}$ & 2 & $\begin{array}{l}\text { Epitheliopathy, } \\
\text { keratoneuritis, iritis }\end{array}$ & $\begin{array}{l}\text { Acanthamoeba } \\
\text { epithelial scrape }\end{array}$ & 4 & 14 & $6 / 9$ & $6 / 9$ & None \\
\hline 12 & Iritis & Dexamethasone & 1 & $\begin{array}{l}\text { Keratoneuritis, } \\
\text { stromal infiltrates }\end{array}$ & $\begin{array}{l}\text { Acanthamoeba } \\
\text { epithelial scrape }\end{array}$ & 3 & 8 & $6 / 60$ & $6 / 6$ & $\begin{array}{l}\text { Early stromal oedema, } \\
\text { resolved in } 2 \text { days with } \\
\text { topical steroids }\end{array}$ \\
\hline
\end{tabular}

HSK, herpes simplex keratitis; PK, penetrating keratopathy; VA, visual acuity. 


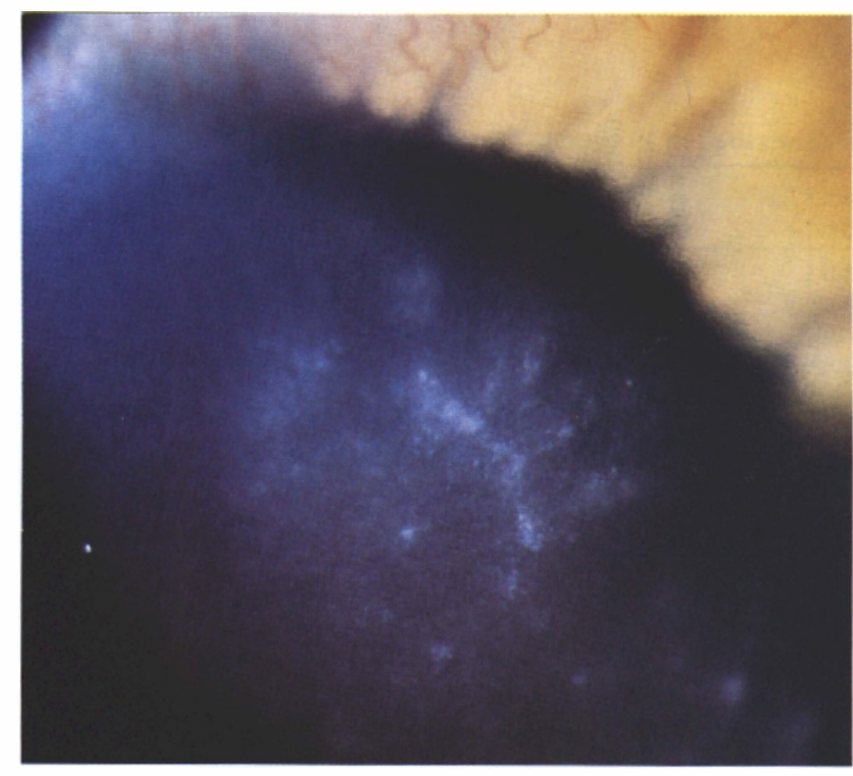

(a)

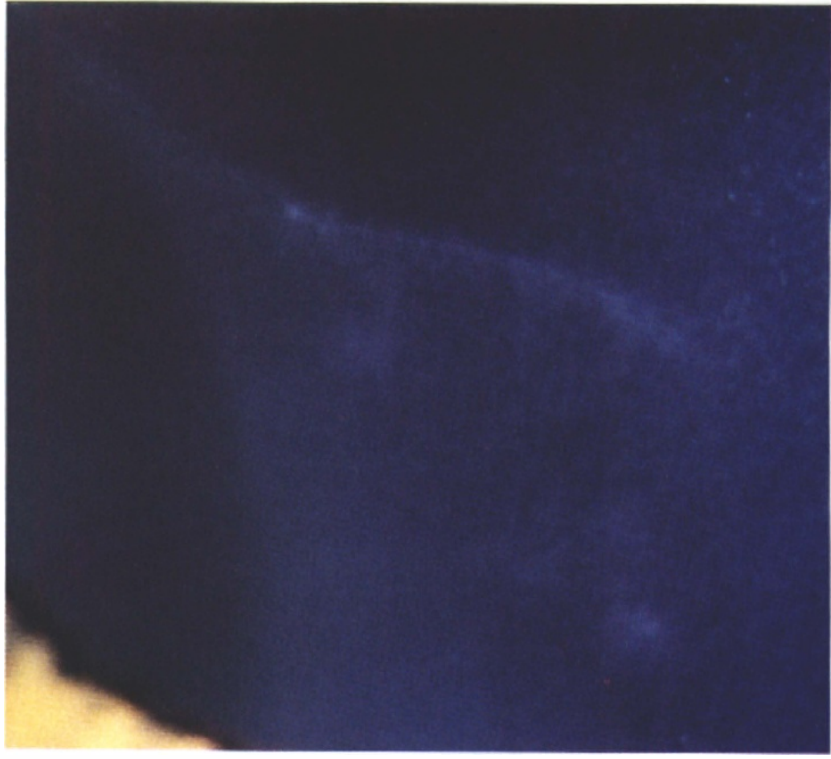

(b)

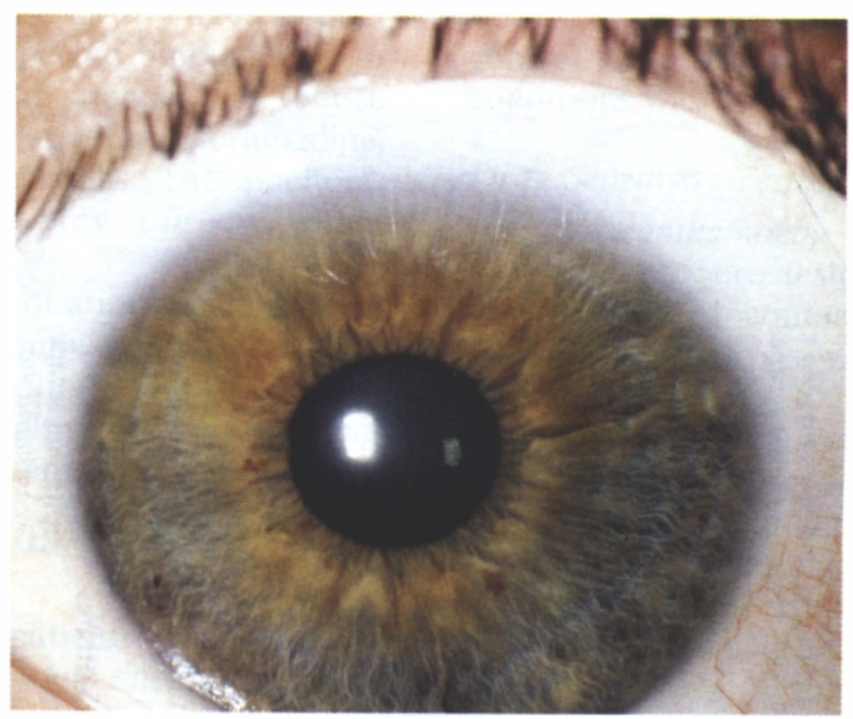

(c)

Fig. 1. Patient no. 4. (a) Corneal epitheliopathy and anterior stromal infiltration with Acanthamoeba keratitis at early diagnosis. (b) Signs after 10 days of chlorhexidine and propamidine therapy are less marked but keratoneuritis is still present. (c) Normal eye 8 months after cessation of successful therapy of Acanthamoeba keratitis.

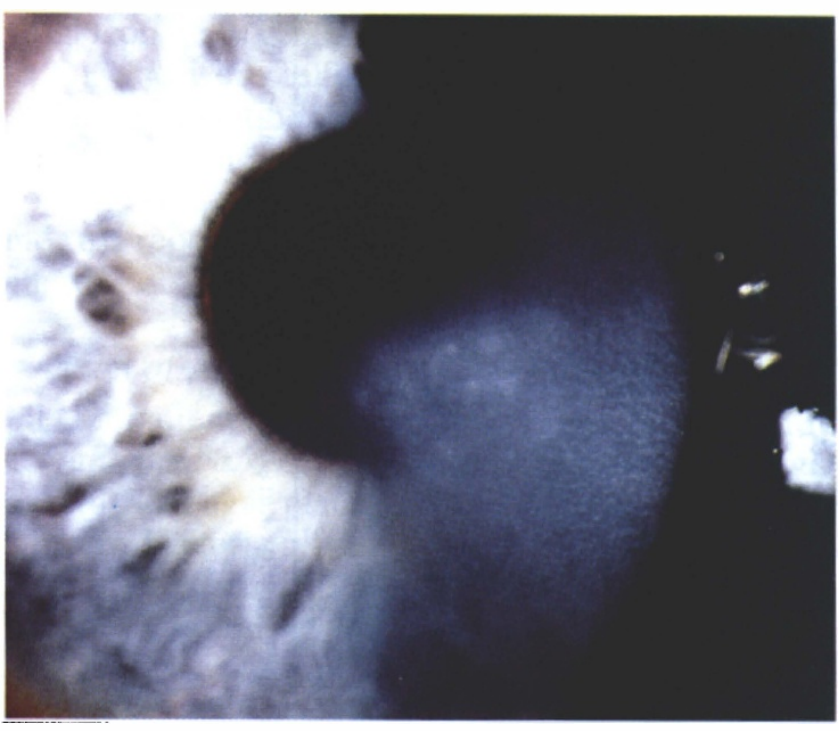

Fig. 2. Patient no. 12. Acute localised stromal oedema 14 days after starting chlorhexidine and propamidine therapy.

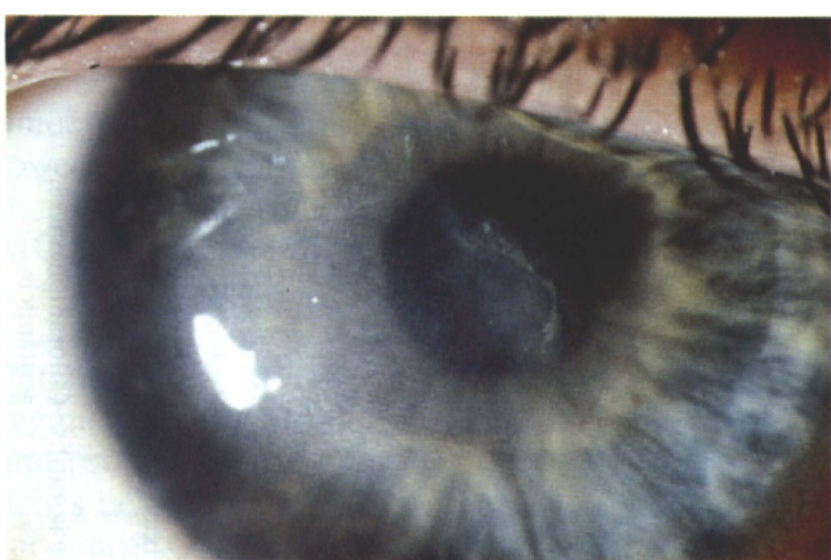

Fig. 3. Patient no. 2. Localised immuno-inflammatory effect 6 months after starting chlorhexidine and propamidine therapy. 
were observed. Ancillary treatment included flurbiprofen (100 mg oral t.d.s.) for pain relief, mydriasis and a non-steroidal anti-inflammatory effect.

Patients noted early reduction in the severity of their symptoms with an early symptom-free chemotherapeutic effect gained at a mean time of 3 weeks (Table II). The signs resolved or stabilised in a mean time of 11 weeks (range 5-28 weeks), with resultant anterior stromal scarring in some patients.

Patients received treatment for between 2 and 6 months. One patient (no. 4) ignored medical advice and stopped treatment at 2 months, but remained in good vision without recrudescence up to 10 months later (Fig. 1). With one exception (no. 2), all patients recovered 6/9 vision; patient no. 2 developed anterior stromal scarring which reduced acuity to $6 / 18$ part with best refraction. All 12 patients were closely observed for symptoms and signs suggestive of drug toxicity to the conjunctival and corneal epithelium and the stroma. No clinical manifestations of such a toxic response were observed, albeit the degree of inflammation present on initial presentation was considerable.

A patient (no. 1) with atopy, psoriasis and blepharitis developed a secondary bacterial keratitis at 11 weeks which progressed rapidly to perforation despite appropriate anti-microbial chemotherapy. ${ }^{4} \mathrm{~A}$ penetrating keratoplasty was performed but culture yielded no amoebal growth. Chlorhexidine and propamidine were continued with fortified gentamicin $1.5 \%$ and cefuroxime $5 \%$. The graft did not become reinfected with Acanthamoeba. Four months later a further episode of bacterial keratitis developed around two sutures in the graft. This responded to supervised, intensive topical antibiotics. Subsequently the visual acuity recovered to $6 / 6$ with best correction.

Non-toxic complications of combination therapy are given in Table II. Three patients (nos. 6, 9 and 12) developed marked stromal infiltration at the site of the infection 10-14 days following commencement of therapy (Fig. 2). This was treated in one patient (no. 12) with topical steroid drops and resolved within 3 days; in the other patients (nos. 6,9), no additional therapy was employed when the infiltrate resolved spontaneously after 2 weeks. The chlorhexidine and propamidine regimen continued throughout in all three patients.

A late immuno-inflammatory complication developed in two patients (no. 2, Fig. 3; no. 9) with an 'apparent' relapse of the infection at the site of the original stromal scarring. In one case (no. 9) the lesion was scraped but yielded no growth of Acanthamoeba; chlorhexidine and propamidine were restarted until lack of viable amoebae was confirmed, but this therapy was without success. The lesion resolved, however, in several days when topical steroids were introduced. For the other case (no. 2), steroids had been used in low dosage in the preceding months and were similarly effective when given in high dosage concurrently with chlorhexidine and propamidine. In this patient there was an increase in corneal opacity due to more marked anterior corneal stromal oedema which was identified at a routine visit; the visual acuity was reduced to $6 / 36$ and the overlying epithelium showed irregularity without frank ulceration.

\section{Acanthamoeba Sensitivity Tests}

Drug sensitivity data for trophozoites and cysts of the 12 Acanthamoeba isolates against chlorhexidine, alexidine, PHMB, propamidine, pentamidine and hexamidine are shown in Fig. 4. For trophozoites, chlorhexidine was the most active compound (modal MTAC, 1.6) followed by PHMB (modal MTAC, 3.2), while for the diamidines, propamidine was the most active (modal MTAC, 6.3). The Vahlkampfia sp. isolated from patient no. 4 was similarly sensitive to both chlorhexidine and propamidine.

For cysts, chlorhexidine, alexidine and PHMB yielded similar effects (modal MCC, 6.3) (Fig. 4a). Propamidine, pentamidine and hexamidine showed less sensitivity (modal MCC, 12.5, 25.0, 12.5 respectively (Fig. 4b).

For neomycin, all trophozoites with the exception of one case $^{4}$ (no. 1) were sensitive (MTAC, 10 $\mu \mathrm{g} / \mathrm{ml}$ ); conversely, cysts from 11 of 12 cases were resistant to clinically achievable concentrations (case no. 9 was sensitive, with an MCC of $10 \mu \mathrm{g} / \mathrm{ml}$ ).

\section{DISCUSSION}

All 12 patients with corneal culture-proven Acanthamoeba keratitis had been wearing soft contact lenses. Nine of the $12(75 \%)$ had been wearing ionic, high water content lenses classified by the US Food and Drug Administration (FDA) as group 4. Two had been wearing non-ionic, low water content (FDA group 1) lenses. Data pertaining to the remaining contact lens type was unavailable. Similar reporting of an association between group 4 contact lenses and Acanthamoeba keratitis has been made previously by our group for five patients ${ }^{11,12}$ and by others for at least 19 of 35 patients. ${ }^{13}$ Nine patients had been recommended a chlorine disinfection tablet system (Softab, Alcon). Previous reports ${ }^{11-13}$ have highlighted the association between Acanthamoeba keratitis and the use of chlorine-based systems, which are not active against Acanthamoeba cysts in vitro. ${ }^{14,15}$

Effectivity of therapy was influenced by the time taken to establish the definitive diagnosis. Resolution gradually occurred within 4 weeks. There was relief of pain, photophobia and lid oedema within 1 week if the clinical diagnosis had been made early. ${ }^{16}$ Early resolution at 2 weeks was apparent with disruption of the previously infiltrated epithelial layer, when the 

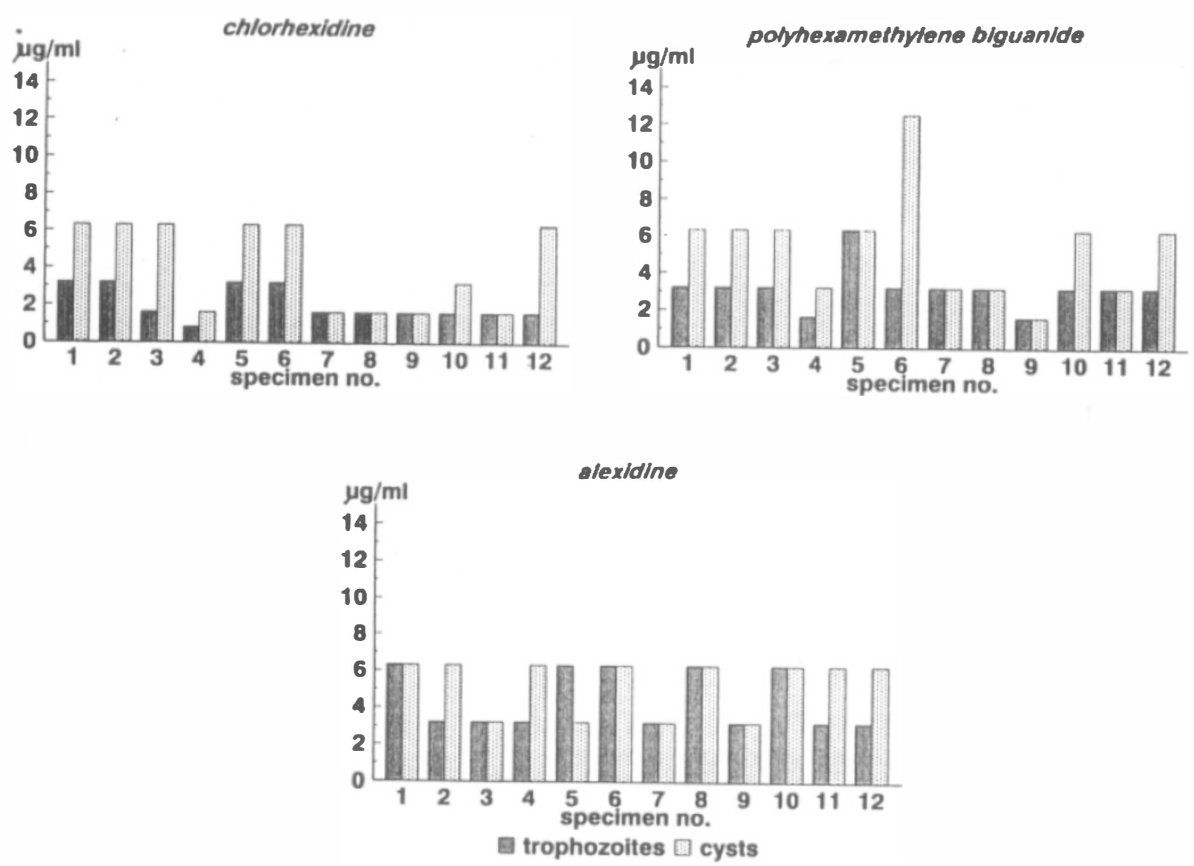

(a)
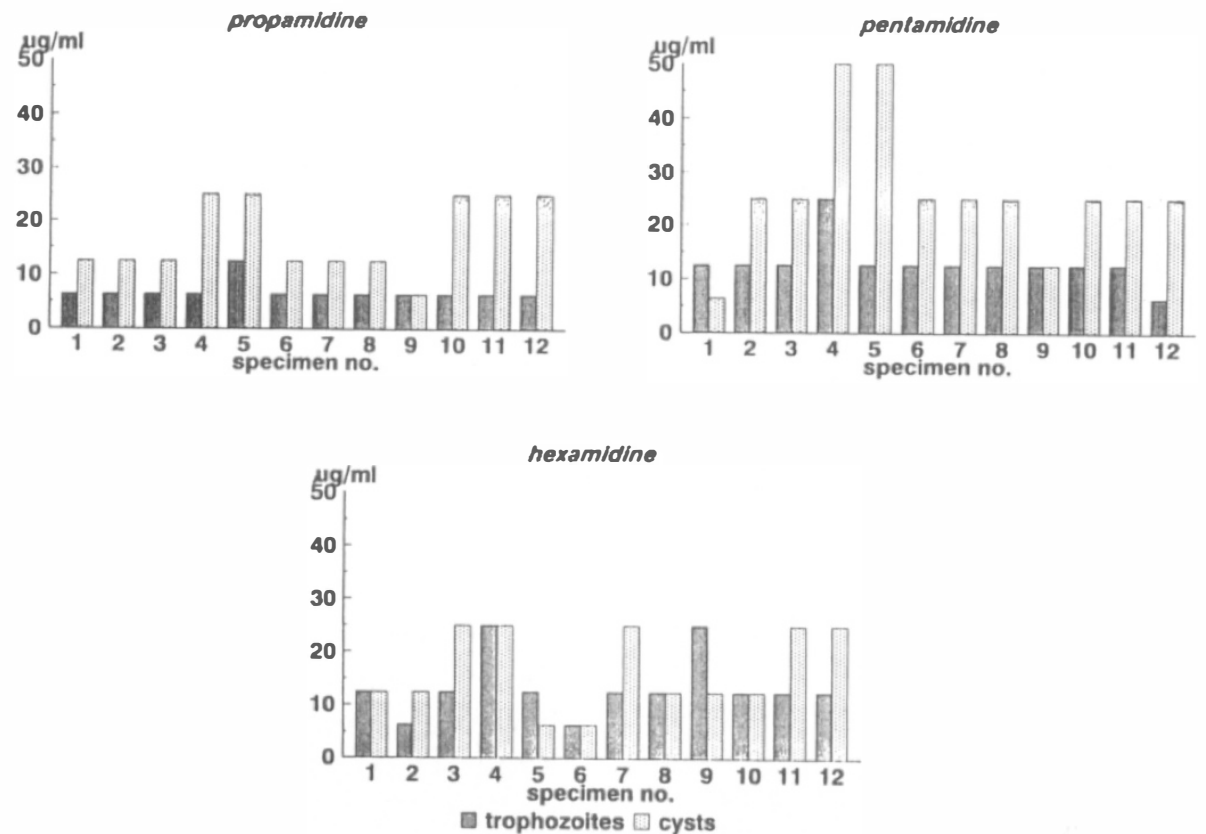

(b)

Fig. 4. (a) Minimum amoebacidal effects of cationic antiseptics. (b) Minimum amoebacidal effects of aromatic diamidines.

perineural inflammatory infiltrate could be seen resolving. Late resolution included the development of sub-epithelial anterior stromal scarring in an otherwise normal eye; this was recorded as occurring between 4 and 28 weeks after initiation of the combination therapy.

Therapy involved courses of 2 to 7 months; no patient required additional anti-Acanthamoeba drugs. One patient (no. 1) underwent keratoplasty, as a result of secondary bacterial infection, with graft survival and visual acuity of $6 / 6$ after 2 years. This compares with previous experience when trophozoites were identified in corneas at the time of keratoplasty, ${ }^{17}$ when graft survival was limited to $20 \%$ at 2 years whilst drugs other than cationic antiseptics were used.

A diverse range of drugs and regimens have been used in an attempt to identify a therapy for Acanthamoeba keratitis which would provide consistent resolution of the condition. ${ }^{4}$ One such treatment combined propamidine with neomycin. ${ }^{1}$ Using this combination, approximately $50 \%$ of 
patients were not cured medically ${ }^{18}$ and continued to suffer severe pain and gradual destruction of the cornea. This was probably due to both of these drugs being relatively ineffective against Acanthamoeba cysts and to resistance of some strains to both propamidine and neomycin. ${ }^{4}$ Such resistance has not as yet been experienced in a considerable number of patients treated with PHMB in combination therapy ${ }^{19}$ or hexamidine as monotherapy ${ }^{20}$ - albeit only 2 patients have been successfully treated with the latter drug. All 12 isolates were sensitive to hexamidine, which can thus be considered an alternative aromatic diamidine for ocular use. Since in our experience ocular isolates appear more sensitive to commercially available formulations of propamidine (as Brolene) than to those containing hexamidine (Desmodine), we cannot recommend that the latter be used as a first-line drug ${ }^{21}$ if Brolene is available. We suggest, however, that drug sensitivity tests should always be performed as soon as possible following initiation of treatment for Acanthamoeba keratitis.

Considerable care was taken in each of the 12 cases to look clinically for toxic effects related to use of either chlorhexidine or propamidine, but no such reaction was perceived. Localised anterior stromal infiltrate at the site of the infection developed in three patients after 10 days of treatment (Fig. 2). This may have been consequent to release of toxic cellular components of Acanthamoeba into the cornea as a result of the rapid acanthamoebicidal effect of chlorhexidine. This localised effect resolved after 2

Table III. Review of studies concerned with chlorhexidine toxicity

\begin{tabular}{|c|c|c|c|}
\hline Author and year & Model or study & Chlorhexidine gluconate & Effect \\
\hline $\begin{array}{l}\text { Animal model } \\
\text { Roed } 1994^{27}\end{array}$ & $\begin{array}{l}\text { Rat (Wistar, albino), phrenic } \\
\text { nerve diaphragm }\end{array}$ & $\begin{array}{l}0.0001-0.01 \% \text { as soaking } \\
\text { solution }\end{array}$ & $\begin{array}{l}\text { Neuromuscular inhibition (post- } \\
\text { synaptic) at } 0.01 \%\end{array}$ \\
\hline Zampatti et al. $1994^{28}$ & $\begin{array}{l}\text { Bovine tooth in vitro model with } \\
\text { S. sanguis }\end{array}$ & $0.004 \%$ impregnated toothpaste & $\begin{array}{l}\text { Inhibition of colonisation of } \\
\text { enamel with } S . \text { mutans }\end{array}$ \\
\hline Pucher et al. $1994^{29}$ & $\begin{array}{l}\text { Cultured fibroblasts (gingival, } \\
\text { periodontal, foreskin) }\end{array}$ & $\begin{array}{l}0.005 \% \text { and } 0.002 \% \text { for } 1 \text { hour } \\
\text { and } 0.12 \% \text { for } 30 \text { seconds }\end{array}$ & $\begin{array}{l}0.002 \% \text { minimally cytotoxic; } \\
\text { suppressed cell division; reduced } \\
\text { contraction of collagen gel }\end{array}$ \\
\hline Celdran et al. $1993^{30}$ & $\begin{array}{l}\text { Rat }^{\mathrm{a}} \text { (Wistar), intraperitoneal } \\
\text { challenge with } E \text {. coli \& } 2 \mathrm{ml} \mathrm{chl}\end{array}$ & $\begin{array}{l}0.05 \% \text { solution }(2 \mathrm{ml}) \text { injected } \\
\text { intraperitoneally with } E . \text { coli }\end{array}$ & $\begin{array}{l}\text { Increased neutrophils after } 24 \\
\text { hours; bactericidal effect; no } \\
\text { toxicity }\end{array}$ \\
\hline Severyns et al. $1991^{31}$ & $\begin{array}{l}\text { Rat }^{\mathrm{a}} \text { (Wistar), dissection of } \\
\text { femoral vessels and irrigation }\end{array}$ & $\begin{array}{l}0.001 \%, 0.02 \%, 0.05 \% \text { solution } \\
\text { for } 10 \text { minutes }\end{array}$ & $\begin{array}{l}\text { No toxicity on vascular } \\
\text { endothelium }\end{array}$ \\
\hline Archer et al. $1990^{32}$ & $\begin{array}{l}\text { Domestic pig, full-thickness skin } \\
\text { wounds }\end{array}$ & $\begin{array}{l}0.2 \% \text { solution packed and sealed } \\
\text { into wound }\end{array}$ & $\begin{array}{l}\text { Reduced granulation tissue by } \\
80 \% \text {; toxic for new epithelium }\end{array}$ \\
\hline Niedner and Schopf $1986^{33}$ & $\begin{array}{l}\text { Guinea-pig (Pibright white), } \\
\text { deep skin wound }\end{array}$ & $0.5 \%$ impregnated gel & $\begin{array}{l}\text { Reduced granulation tissue by } \\
66 \%\end{array}$ \\
\hline Brennan et al. $1986^{34}$ & $\begin{array}{l}\text { Rat }\left(\text { Sprague-Dawley }{ }^{\mathrm{a}}\right) \text {, deep } \\
\text { skin wound }\end{array}$ & $\begin{array}{l}0.05 \% \text { impregnated hydrogel } \\
\text { paste }\end{array}$ & No delay to wound healing \\
\hline Bowes Hamill et al. $1984^{35}$ & $\begin{array}{l}\text { Rabbit (pigmented), } 6 \mathrm{~mm} \\
\text { corneal abrasion and de- } \\
\text { epithelialisation }\end{array}$ & $\begin{array}{l}0.1 \%, 0.2 \%, 0.4 \%, 0.5 \%, 1 \% \text {, } \\
2 \%, 4 \% \text { as irrigant solution on } \\
\text { one occasion }\end{array}$ & $\begin{array}{l}<1 \% \text { did not delay healing at } 40 \\
\text { hours; } 2 \% \text { delayed at } 120 \text { hours; } \\
4 \% \text { epithelial loss }\end{array}$ \\
\hline Platt and Bucknall $1984^{36}$ & $\begin{array}{l}\text { Guinea-pig (albino), deep skin } \\
\text { wound with S. aureus }\end{array}$ & $\begin{array}{l}0.01 \%, 0.02 \%, 0.05 \% \text { wound } \\
\text { irrigation }\end{array}$ & $\begin{array}{l}\text { No delay to wound healing; } \\
\text { inactivation of } S \text {. aureus }\end{array}$ \\
\hline Green et al. $1980^{37}$ & $\begin{array}{l}\text { Rabbit (albino), corneal excision } \\
\text { and bathing in vitro }\end{array}$ & $\begin{array}{l}0.05 \% \text { solution for soaking } \\
\text { whole cornea }\end{array}$ & $\begin{array}{l}\text { Stromal swelling }- \text { ? relevance to } \\
\text { clinical use }\end{array}$ \\
\hline Browne et al. $1975^{38}$ & $\begin{array}{l}\text { Rabbit (NZ white), instillation } \\
\text { into cul-de-sac and impregnated } \\
\text { contact lens wear }\end{array}$ & $\begin{array}{l}0.005 \%, 0.0165 \%, 0.05 \% \\
\text { instilled in } 0.1 \mathrm{ml} 0.004 \% \text {, } \\
0.005 \%, 0.01 \% \text { solutions for lens } \\
\text { impregnation }\end{array}$ & $\begin{array}{l}\text { Circumcorneal injection and } \\
\text { conjunctivitis (Draize scale }<1 \text { ) } \\
\text { with } 0.05 \% \text {; no other sequelae }\end{array}$ \\
\hline $\begin{array}{l}\text { Human/animal model } \\
\text { Hamed et al. } 1987^{39}\end{array}$ & $\begin{array}{l}\text { (1) Two patients (inadvertent } \\
\text { use) } \\
\text { (2) Rabbit (albino) }\end{array}$ & $\begin{array}{l}\text { (1) 'Hibiclens' }(4 \%+4 \% \\
\text { alcohol) } \\
\text { (2) 'Hibiclens' irrigated onto } \\
\text { cornea for 5-15 minutes }\end{array}$ & $\begin{array}{l}\text { Total corneal opacification; total } \\
\text { epithelial sloughing; stromal } \\
\text { oedema; endothelium toxicity; } \\
\text { stromal vascularisation }\end{array}$ \\
\hline $\begin{array}{l}\text { Human study } \\
\text { Albandar et al. } 1994^{40}\end{array}$ & $\begin{array}{l}20 \text { years of use as mouth wash/ } \\
\text { gel in Norway (review) }\end{array}$ & $\begin{array}{l}1 \% \text { gel b.d. and } 0.2 \% \\
\text { mouthwash b.d. on a continual } \\
\text { basis sold without prescription }\end{array}$ & $\begin{array}{l}\text { Satisfactory treatment of } \\
\text { periodontitis and gingivitis } \\
\text { without toxicity }\end{array}$ \\
\hline Jenkins et al. $1994^{41}$ & 28 volunteers & $\begin{array}{l}0.01 \%, 0.05 \%, 0.1 \%, 0.2 \% \\
\text { mouthwash rinses }\end{array}$ & $\begin{array}{l}0.01 \% \text { effective response with } \\
\text { plaque reduction; non-toxic in } \\
\text { use for } 0.01-0.2 \%\end{array}$ \\
\hline Emilson $1994^{42}$ & Review of regular use & $\begin{array}{l}1 \% \text { gel b.d. or b.d. } 0.2 \% \\
\text { mouthwash }\end{array}$ & $\begin{array}{l}\text { Use shown to prevent caries; } \\
\text { non-toxic }\end{array}$ \\
\hline
\end{tabular}

${ }^{\mathrm{a}}$ Presumed but not stated to be pigmented. 
weeks in two patients without topical steroid therapy but with continuing chlorhexidine, and after several days in one other who was given steroids.

The immuno-pathogenesis of the late inflammatory phenomenon in the cornea experienced in two patients at 6 months has been neither recognised nor recorded previously. This effect (Fig. 3) settled quickly with steroids. Such features of this late effect are known to occur in association with other infections of the cornea. With Onchocerca volvulus punctate keratitis, for example, an inflammatory infiltrate comprising lymphocytes and eosinophils with concomitant localised oedema ${ }^{22}$ was a common feature of diethylcarbamazine-treated patients, the reaction being consequent to a cell-mediated immune response to the dead microfilariae, which were localised in the centre of ill-defined opacities. The development of such cell-mediated immunity ${ }^{23}$ to the presence of Acanthamoeba antigens in the cornea may also be responsible for the severe scleritis suffered by some patients with chronic Acanthamoeba keratitis, ${ }^{24}$ which itself may be immuno-inflammatory in origin and usually requires high-dose steroid therapy to suppress it. Pineda and Dohlman ${ }^{25}$ have recently concluded that the role of steroids in Acanthamoeba infection is ambiguous, while D'Aversa et $_{\text {al }}{ }^{26}$ have advised against their use in acute infection, because of the risk of compromising the host inflammatory response against Acanthamoeba; these workers reserve steroids for later complications. Our experience suggests that steroids have a role in controlling late immuno-inflammatory responses, when the amoebae have been killed and antigen remains bound to the corneal stroma, but this aspect clearly requires further elucidation.

Cellular toxicity from chlorhexidine, as described in the studies referred to in Table III and using various animal models, ${ }^{27-42}$ was not seen in any of the treated patients. Some of these animal studies were performed on albinos, however, so findings must be interpreted with caution; ${ }^{43}$ use of albinos is contra-indicated for toxicity studies, these animals having multiple biochemical defects. Furthermore, these observations are consistent with the safe use of chlorhexidine which has been extensively recorded from dental practice in humans. Although the physiology and biochemistry of oral mucus are different to those of the eye, there is no reason to suggest that chlorhexidine at the given concentration is not a safe therapeutic agent for the treatment of Acanthamoeba keratitis. It should be noted, however, that chlorhexidine is not completely without toxicity. It is toxic for certain mammalian cells when used at concentrations of $1 \%$ or greater (Table III). It is toxic to neuroepithelial cells at lower concentrations. Thus, it must not come into contact with the retina or middle ear, ${ }^{44}$ nor must it have tissue involvement in neurosurgery. These features do not appear to influence recovery from Acanthamoeba keratoneuritis, and loss of corneal sensation does not appear to follow this condition, or its treatment with chlorhexidine.

Effective treatment of Acanthamoeba keratitis has been provided by combination therapy which includes polyhexamethylene biguanide (PHMB). ${ }^{2,3.45}$ This demonstrates the usefulness of the cationic antiseptics as a class of drug for treatment of Acanthamoeba keratitis. PHMB, however, is manufactured principally as an industrial grade sterilant. It is used in cosmetics and soaps as a preservative, as an algastatic compound in swimming pools, and as a constituent of some contact lens disinfecting fluids. Unlike chlorhexidine, ${ }^{7}$ it is not licensed for therapy of infectious disease because of a paucity of clinical trials and toxicity studies in humans. Chlorhexidine has a persistent binding effect on tissue for up to 24 hours after application. It is a smaller molecule than PHMB and may permeate better into the corneal stroma. The findings from this study, suggested but not proven from Iowa ${ }^{46}$ have shown that chlorhexidine, in combination with propamidine, provides rapid and successful therapy for the treatment of Acanthamoeba infection of the cornea. This will also be a useful addition to treatment regimens for countries where contact lenses are becoming widely available. ${ }^{4,48}$

The authors thank Professor Alan Tomlinson for optometric advice and Mr John McCormack for photography.

\section{REFERENCES}

1. Wright P, Warhurst D, Jones BR. Acanthamoeba keratitis successfully treated medically. $\mathrm{Br} \mathrm{J}$ Ophthalmol 1985;69:778-82.

2. Larkin DFP, Kilvington S, Dart JKG. Treatment of Acanthamoeba keratitis with polyhexamethylene biguanide. Ophthalmology 1992;99:185-91.

3. Varga JH, Wolf TC, Jensen HG, Parmley VC, Rowsey JJ. Combined treatment of Acanthamoeba keratitis with propamidine, neomycin and polyhexamethylene biguanide. Am J Ophthalmol 1993;115:466-70.

4. Hay J, Kirkness CM, Seal DV, Wright P. Drug resistance and Acanthamoeba keratitis: the quest for alternative antiprotozoal chemotherapy. Eye 1994;8: 555-63.

5. Elder MJ, Kilvington S, Dart JKG. A clinicopathologic study of in vitro sensitivity testing and Acanthamoeba keratitis. Invest Ophthalmol Vis Sci 1994;35:1059-64.

6. Tirado-Angel J, Gabriel MM, Wilson L, Ahearn R. Effects of polyhexamethylene biguanide and chlorhexidine digluconate on 4 species of free-living Acanthamoeba in vitro. Invest Ophthalmol Vis Sci 1995;36(4, Suppl):S327.

7. Seal DV, Hay J, Kirkness CM. Chlorhexidine or polyhexamethylene biguanide for Acanthamoeba keratitis. Lancet 1995;345:136.

8. Booth A, Morrell AJ. Acanthamoeba keratitis. Eye 1994;8:719-20.

9. Armstrong M. The laboratory investigation of infective keratitis. Br J Biomed Sci 1994;51:65-72. 
10. Hay J, Kinnear F, Kirkness CM, Seal DV. Acanthamoeba keratitis: laboratory diagnosis, characterisation of protozoa and treatment. Scottish Centre Infect Environ Health 1995;29(95/17):90-1.

11. Seal DV, Hay J, Devonshire P, Kirkness CM. Acanthamoeba and contact lens disinfection: should chlorine be discontinued? $\mathrm{Br} \mathrm{J}$ Ophthalmol 1993;77:128.

12. Sarwar N, Griffith GAP, Loudon K, Tullo AB, Efron E. Acanthamoeba keratitis associated with disposable hydrogel contact lenses disinfected daily with chlorinebased care system. J Br Contact Lens Assoc 1993;16: $15-8$.

13. Radford CF, Bacon AS, Dart JKG, Minassian DC. Risk factors for Acanthamoeba keratitis in contact lens users: a case-control study. BMJ'1995;310:1567-70.

14. Seal DV, Hay J. Contact lens disinfection and Acanthamoeba: problems and practicalities. Pharm J 1992;248:717-9.

15. Hay J, Seal DV, Connor R, Simmons PA, Tomlinson A. Disinfection and sonication: effect on association of Acanthamoeba cysts with an ionic, high water content contact lens. J Br Contact Lens Assoc 1995;18:5-8.

16. Bacon AS, Dart JKG, Ficker LA, Matheson MM, Wright P. Acanthamoeba keratitis: the value of early diagnosis. Ophthalmology 1993;100:1238-43.

17. Ficker LA, Kirkness C, Wright P. Prognosis for keratoplasty in Acanthamoeba keratitis. Ophthalmology 1993;100:105-10.

18. Ficker L, Seal DV, Warhurst D, Wright P. Acanthamoeba keratitis: resistance to medical therapy. Eye 1990;4:835-8.

19. Gray TB, Gross KA, Cursons RTM, Shewan JF. Acanthamoeba keratitis: a sobering case and a promising new treatment. Aust NZ J Ophthalmol 1994;22: 73-6.

20. Brasseur G, Favennec L, Perrine D, Chenu JP, Brasseur P. Successful treatment of Acanthamoeba keratitis by hexamidine. Cornea 1994;13:456-62.

21. Perrine D, Chenu JP, Georges P, Lancelot JC, Saturnino C, Robba M. Amoebicidal efficiencies of various diamidines against two strains of Acanthamoeba polyphaga. Antimicrob Ag Chemother 1995;39:339-42.

22. Pearlman E, Lass JH. Keratitis due to onchocerciasis. Ophthalmol Clin North Am 1994;7:641-8.

23. Hendricks RL, Tang Q. Cellular immunity and the eye. In: Pepose JS, Holland GN, Wilhelmus KR, editors. Ocular infection and immunity. St Louis: Mosby-Year Book, 1996:71-95.

24. Dougherty PJ, Binder PS, Mondino BJ, Glasgow BJ. Acanthamoeba sclerokeratitis. Am J Ophthalmol 1994;117:475-9.

25. Pineda R, Dohlman $\mathrm{CH}$. The role of steroids in the management of Acanthamoeba keratitis, fungal keratitis and epidemic keratoconjunctivitis. Int Ophthalmol Clin 1994;34:19-31.

26. D'Aversa G, Stern GA, Driebe T. Diagnosis and successful medical treatment of Acanthamoeba keratitis. Arch Ophthalmol 1995;113:1120-3.

27. Roed A. Effects of chlorhexidine on the isolated rat phrenic nerve-diaphragm preparation. Pharmacol Toxicol 1994;74:10-6.

28. Zampatti O, Roques Ch, Michel G. An in vitro mouth model to test anti-plaque agents: preliminary studies using a toothpaste containing chlorhexidine. Caries Res 1994;28:35-42.
29. Pucher JJ, Daniel JC. The effects of chlorhexidine digluconate on human fibroblasts in vitro. J Periodontol 1992;63:526-32.

30. Celdran A, Inarrea P, Fernandez J, Larrocha C, Madero R. Neutrophil dynamics in abdominal cavity of peritonitic rats treated with antiseptics. Int Surg 1993;78:354-6.

31. Severyns AM, Lejeune A, Rocoux G, Lejeune G. Nontoxic antiseptic irrigation with chlorhexidine in experimental revascularization in the rat. J Hosp Inf 1991;17: 197-206.

32. Archer H, Barnett S, Irving S, Middleton K, Seal DV. A controlled model of moist wound healing: comparison between semi-permeable film, antiseptics and sugar paste. J Exp Pathol 1990;71:155-70.

33. Niedner R, Schopf E. Inhibition of wound healing by antiseptics. Br J Dermatol 1986;115(Suppl 31): 41-4.

34. Brennan SS, Foster ME, Leaper DJ. Antiseptic toxicity in wounds healing by secondary intention. J Hosp Inf 1986;8:263-7.

35. Bowes Hamill M, Osato MS, Wilhelmus KR. Experimental evaluation of chlorhexidine gluconate for ocular antiseptics. Antimicrob Ag Chemother 1984;26:793-6.

36. Platt J, Bucknall RA. An experimental evaluation of antiseptic wound irrigation. J Hosp Inf 1984;5:181-8.

37. Green K, Livingston V, Bowman K, Hull DS. Chlorhexidine effects on corneal epithelium and endothelium. Arch Ophthalmol 1980;98:1273-8.

38. Browne RK, Anderson AN, Charvez BW, Azzarello RJ. Ophthalmic response to chlorhexidine digluconate in rabbits. Toxicol Appl Pharmacol 1975;32:621-7.

39. Hamed LM, Ellis FD, Boudreault G, Wilson FM, Helveston EM. Hibiclens keratitis. Am J Ophthalmol 1987;104:50-6.

40. Albandar JM, Gjermo P, Preus HR. Chlorhexidine use after two decades of over-the-counter availability. J Periodontol 1994;65:109-12.

41. Jenkins S, Addy M, Newcombe RG. Dose response of chlorhexidine against plaque and comparison with triclosan. J Clin Periodontol 1994;21:250-5.

42. Emilson CG. Potential efficacy of chlorhexidine against Mutans streptococci and human dental caries. J Dent Res 1994;73:682-91.

43. Creel D. Inappropriate use of albino animals as models in research. Pharmacol Biochem Behav 1980;12: 969-77.

44. Bicknell PG. Sensorineural deafness following myringoplasty operations. J Laryngol Otol 1971;85:957-61.

45. Mills RA, Wilhelmus KR, Osato MS, Pyron M. Polyhexamethylene biguanide in the treatment of Acanthamoeba keratitis. Aust NZ J Ophthalmol 1993;21:277-8.

46. Mathers WD, Sutphin JE, Folberg R, Meier P, Wenzel RP, Elgin R. Outbreak of keratitis presumed to be caused by Acanthamoeba. Am J Ophthalmol 1996;121: $129-42$.

47. Kamel AGM, Norazah A. First case of Acanthamoeba keratitis in Malaysia. Trans R Soc Trop Med Hyg 1995;89:652.

48. Seal DV, Hay J, Kirkness CM. Acanthamoeba keratitis and contact lens wear: the need for a global strategy for prevention of corneal infection. Community Eye Health 1995;8:4-6. 